\title{
International Students in Academic Libraries: A User Survey
}

\section{Mary Beth Allen}

A study was undertaken to identify characteristics of the international student population and determine these students' patterns of library use. Analyses were carried out to measure a number of relationships concerning the students' prior use of microcomputers, both in libraries and otherwise, and their current perceived difficulties using libraries. Findings suggest that not all international students arrive in the United States with appropriate information retrieval skills to take advantage of automated bibliographic access systems. Libraries may need to make special efforts to extend instructional services to these students.

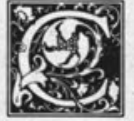

ultural diversity on college campuses has increased in recent years. One segment of the multicultural environment of universities is international students. In academic year $1989 / 1990$, there were more than 386,000 international students enrolled in colleges and universities in the United States, up 5.6\% from the previous year. This was the largest increase in seven years. ${ }^{1}$ Those who work in higher education share an agreement to embrace both cultural diversity and unity, and to actively remove barriers to communication and learning.

To ease the transition of international students from their indigenous culture to American culture, most universities operate an office of international student affairs which performs the basic welcoming and orientation function for students newly arrived from other countries. Many academic departments also do their share to make new students feel com- fortable and, whether intentionally or not, may serve as a smaller community through which new persons can learn about academic life in the United States and gain a sense of what is expected of them as they make progress toward completing a degree. As a crucial component of serious scholarship at any level, the library is also responsible, not only for making its collections and services available to the scholarly community and the public butalso for teaching newcomers the strategies and processes by which they can independently maneuver through the increasingly complex variety of bibliographic access systems.

\section{BACKGROUND AND LITERATURE REVIEW}

Currently, there is a strong interest in higher education (and among public service librarians) in investigating the need for programs and services targeted at special populations, such as international

Mary Beth Allen is Applied Life Studies Librarian and Assistant Professor of Library Administration at the University of Ilinois Library, Urbana, Illinois 61801. This research was funded in part by a grant from the University of Illinois Library Research and Publications Committee. The author wishes to acknowledge assistance from the Library Research Center and participants of the 1991 Advanced Research Institute (GSLIS/Council on Library Resources), and to express appreciation to James A. Hutchinson of the University of Illinois Department of English. 
students. The literature of librarianship contains important contributions that aid our understanding of the difficulties international students face as they begin to use academic libraries in the United States. Excellent overviews of the major writings on the role of bibliographic instruction and other library services for international students have been reported in Ormondroyd and Jacobson..$^{2,3}$ In addition, an examination of the library's role in the pluralistic campus, including appropriate administrative initiatives, can be found in Trujillo and Weber as well as in Welch and Lam. ${ }^{45}$

The literature of librarianship contains important contributions that aid our understanding of the difficulties that international students face as they begin to use academic libraries in the United States.

However, thorough data analysis or "experimental and case studies of the students' problems are almost nonexistent."6 Recent research projects conducted by Dania Bilal, Kwasi Sarkodie-Mensah, Ting Ming Lai, and others are examples of thorough data analysis that have reversed this trend and made a significant contribution to the body of literature on international students' use of United States academic libraries. ${ }^{7}$ Still, most of these studies were completed before the use of microcomputers (such as for OPACs) became such an integral part of the basic library research process. To new international students on our campuses, the presence of microcomputers in the library and the necessity of their use to access vast stores of information might constitute one of the major differences between libraries in their home countries and those in the United States.

In research involving international students who were in the United States seeking a degree in library and information science, Silas Marques de Oliveira compared the strengths of program areas in American library and information science departments with program areas that students entering United States educational institutions considered important or desirable. One of Oliveira's findings was that the library and information science program areas that students considered to be most needed in their home countries were all technological in nature (automation, information services, information transfer, and networking). ${ }^{8}$ The obvious implication is that these international students perceived the technological advances of American libraries to be of interest, and further that such technology was perhaps unavailable to them at home. Oliveira concludes that "the technological areas .... are not only the areas in which most of the [United States] schools consider themselves as having very strong programs, but are also the areas most mentioned as being greatly needed in most of the [foreign] countries represented in this study." A further implication is that use of computers in libraries is not prevalent outside the United States.

\section{PROBLEM STATEMENT}

The present study responds to the need for research aimed at determining what place the library holds in the education process of the diverse population of students on our campuses, which includes international students. It responds to the growing need among academic institutions to assess what perceptions international students have of research libraries, how they use libraries during their academic tenure, and what difficulties they encounter in their efforts to utilize the libraries' services and collections. More specifically, the study examines international students' use of microcomputers for bibliographic access in libraries, and their use of computers for other purposes (word processing, database management, spreadsheets, etc.) outside libraries. The method chosen for the study, which will be described in more detail in a subsequent section, will consist of a survey of the user population and their use of the library. The information obtained will be useful in planning and implementing library services for 
international students, and perhaps for the larger user community.

\section{METHODOLOGY}

The present study was carried out in response to the doctoral research of Kwasi Sarkodie-Mensah. The questionnaire used in the current project closely resembles that of Sarkodie-Mensah, which was completed at two New Orleans, Louisiana, academic libraries; however, neither of those two libraries employed an online catalog at the time, so there is significant interest in complementing the previous work with data gathered at a library like that of the University of Illinois, where utilizing the library's collections (and resources within the state) is synonymous with independently utilizing a variety of computerized information sources. Workstations throughout the main library and in a variety of departmental library locations across campus provide access to an online catalog with library holdings and circulation information not only for the Urbana campus but also for over forty other cooperating university, college, public, and other libraries within the state of Illinois. In addition, many of the workstations provide access to local reference files and locally mounted databases. Other workstations only provide access to databases on CD-ROM. The purpose of conducting this user survey was to test statistically the relationship between the difficulty that international students might experience using the University of Illinois library and the degree of their familiarity with computers. The study examines two areas: (1) online catalogs used in libraries, and (2) other uses of microcomputers outside libraries. The international students were asked:

- if the online catalog was new to them

- if online catalog workshops were new

- whether they found the online catalog difficult to use

- if they had used computers in a library before coming to the University of IIlinois

- whether they had previously used computers for other purposes, such as word processing, programming, etc.
A questionnaire was developed to assess not only computer use but also other primary library use patterns and utilization of collections, services, and facilities by international students. Basic demographic data were also collected. The questionnaire was based in content on the survey instrument used in SarkodieMensah's research, although many questions were modified and additional questions, for example, those related to computer use, were included. ${ }^{10}$ The survey instrument contained thirty-three questions, many of which required or allowed for multiple responses." The six-page questionnaire was initially intended to be as comprehensive as possible concerning the students' library-use patterns. Therefore, the resulting data set is quite large and covers a wide range of crucial library use issues. For practical purposes, the present report will focus specifically on questions aimed at international students' use of computers.

\section{RESEARCH DESIGN}

The university's Office of Administrative Information Systems and Services and Office of International Student Affairs assisted in drawing the random sample population by providing access to university directory information for the 3,401 international students who were on the mailing list of the Office of International Student Affairs. During the fall semester of 1988 , the survey was mailed to a random sample of 750 international students on the Urbana campus. A total of $395(52.7 \%)$ surveys were returned. A double-coding procedure was undertaken, with the first coding done by the Library Research Center staff, and the second one done by the author for the purpose of gaining familiarity with the data. Survey data were tabulated and analyzed using SPSS/PC+.

The Office of Admissions and Records reports that international students account for only $1 \%$ of the 26,000 undergraduate students on the Urbana campus, but they constitute $25 \%$ of the 9,000 graduate students, so the expectation was that the survey population 
would be primarily graduate students. In response to the question "What degree are you working on?" some $59.0 \%$ of the population reported that they were working toward Ph.D.'s and 29.5 indicated that they were pursuing master's degrees, while only $8.4 \%$ were undergraduates. Thus the data gathered in this survey most closely represent patterns of graduate students' library use rather than those of the total international student population.

\section{FINDINGS}

Table 1 shows the frequency distribution of users by field of study or major. On the questionnaire, the students were asked their major or area of concentration. Since the variety of responses was so great, the data were collapsed into eight broad categories representing the gamut of majors. The largest number of students, $25.3 \%$, indicated Engineering was their major. Next highest were Agriculture and Biological Science, with $18.3 \%$ of the population. A close third was Commerce and Business Administration, with $16.4 \%$. Social Sciences represented $13.6 \%$ of the population, while Physical Sciences, Education, and Arts and Humanities each represented $10.4 \%$ or less of the group.

Country of origin is reported in table 2. Again, the data were collapsed because of the wide variety of responses. Seven broad geographic regions represent the collapsed responses. Asia was by far the region with the largest number of respondents, with $54.6 \%$ of the distribution. Europe and Oceania each represented $10.7 \%$ of the population, while South America represented $8.2 \%$, the Middle East $6.8 \%$, North America 5.2\%, and Africa $3.8 \%$.

Concerning the gender question, $31.8 \%$ of the students responding were female, while $68.2 \%$ were male. Another demographic factor examined was the total number of years the international students had already spent in the United States. Some $48.0 \%$ of the students who responded to the survey reported one to three years (table 3 ); $24.7 \%$ reported less than one year, while $21.9 \%$ said four to
TABLE 1

FIELD OF STUDY OF RESPONDENTS

\begin{tabular}{lcc}
\hline Field of Study & Frequency & Valid \% \\
\hline $\begin{array}{l}\text { Commerce and } \\
\text { Business }\end{array}$ & 63 & 16.4 \\
Engineering & 97 & 25.3 \\
Agriculture and & 70 & 18.3 \\
$\quad$ Biology & 52 & 13.6 \\
Social Sciences & 35 & 9.1 \\
Education & 41 & 10.7 \\
Physical Sciences & 24 & 6.3 \\
Arts and Humanities & 1 & .3 \\
\hline Non-degree & &
\end{tabular}

TABLE 2

\begin{tabular}{lcc}
\multicolumn{3}{c}{ GEOGRAPHIC DISTRIBUTION } \\
\hline Geographic Area & Frequency & Valid \% \\
\hline Asia & 200 & 54.6 \\
Africa & 14 & 3.8 \\
Europe & 39 & 10.7 \\
Middle East & 25 & 6.8 \\
North America & 19 & 5.2 \\
South America & 30 & 8.2 \\
Oceania & 39 & 10.7 \\
\hline
\end{tabular}

six years. Only $5.4 \%$ of the respondents had been in the U.S. six years or longer. Later, this variable will be examined further to determine if students who have been in the United States for several years experience less difficulty using the online catalog than those who have recently arrived.

One of the first questions the students were asked in the survey was "How often do you use the library?" In response to this question, $57.4 \%$ of the students said they used the library less than once a day, but at least once a week. Some $24.3 \%$ responded that they used the library at least once a day; $15 \%$ reported their use at less than once a month but at least once a semester, and $3.4 \%$ reported less than once a semester. The data indicate that the majority of international students surveyed con- 
TABLE 3

NUMBER OF YEARS SPENT INU.S.

\begin{tabular}{lcc}
\hline No. of Years & Frequency & Valid \% \\
\hline Less than 1 year & 97 & 24.7 \\
1-3 years & 188 & 48.0 \\
$4-6$ years & 86 & 21.9 \\
6 years or more & 21 & 5.4 \\
\hline
\end{tabular}

sider that the library occupies an important part of the educational environment. To gain an understanding of the students' general comfort level with libraries upon arrival in the United States, they were surveyed to see how prepared they were to use American college and university libraries. In response to the question, "How prepared were you to use American college and university libraries?" $49.9 \%$ of the international students said they were somewhat prepared, $28.0 \%$ felt very prepared, and $22.1 \%$ said they were not at all prepared. The data indicate that over two-thirds of those surveyed might benefit from at least some instruction or orientation to prepare them for using the library.

The data gathered in this survey most closely represent patterns of graduate students' library use rather than those of the total international student population.

One of the major purposes of the survey was to identify what aspects of library use were new to international students, or what features were different from libraries in their home countries. Table 4 shows the frequency distribution for a number of typical library services or characteristics. For this question on the survey, students could choose as many responses as applied, so that the percentages in table 4 represent the percentage of the total sample that responded to each part of the question. Computer database literature searching was chosen most frequently, with $61.2 \%$ of the students reporting that this aspect of library use was new to them. Some $59.6 \%$ said interlibrary loan ("requesting materials not in the library here from another library") was a new service, and $50.5 \%$ said the online catalog was new to them. These three most frequently chosen services all involve use of computers. Online catalog workshops and term paper research counseling also were considered to be relatively new, with $40.1 \%$ of the population responding to each service. The open-stacks characteristic of American libraries has often been reported in the literature as a new concept for foreign students; however, the data here indicate that only $12.0 \%$ of the students surveyed were unfamiliar with finding materials themselves in the open stacks. Thirty-one percent reported that large library collections were new to them, while $28.9 \%$ said microfiche and microfilm were new. Classroom instruction in the library was new to $28.1 \%$, and self-service copy machines were new to $21.6 \%$. Later in the analysis, the newness of the online catalog, unfamiliar to approximately half of the international students surveyed, will be compared with other variables.

To identify library orientation and instruction services the students might

TABLE 4

ASPECTS OF LIBRARIES WHICH WERE NEW TO STUDENTS

\begin{tabular}{lcc}
\hline New Aspect & Frequency & Valid \% \\
\hline $\begin{array}{l}\text { Interlibrary loan } \\
\begin{array}{l}\text { Self-service copy } \\
\text { machines }\end{array}\end{array}$ & 229 & 59.6 \\
$\begin{array}{l}\text { Microfiche, microfilm } \\
\text { Online catalog }\end{array}$ & 111 & 28.9 \\
$\begin{array}{l}\text { Online catalog } \\
\text { workshops }\end{array}$ & 194 & 50.5 \\
$\begin{array}{l}\text { Computer database } \\
\text { lit. search }\end{array}$ & 154 & 40.1 \\
$\begin{array}{l}\text { Open stacks } \\
\text { Large library } \\
\text { collections }\end{array}$ & 235 & 61.2 \\
$\begin{array}{l}\text { Classroom instruction } \\
\text { in the library }\end{array}$ & 116 & 12.0 \\
$\begin{array}{l}\text { Term paper research } \\
\text { counseling }\end{array}$ & 154 & 31.0 \\
\hline
\end{tabular}


TABLE 5

SERVICES STUDENTS HAD TAKEN ADVANTAGE OF

\begin{tabular}{lcc}
\hline $\begin{array}{l}\text { Orientation/ } \\
\text { Instruction Service }\end{array}$ & Frequency & Valid \% \\
\hline $\begin{array}{l}\text { Audiocassette } \\
\text { self-guided tour }\end{array}$ & 13 & 3.4 \\
$\begin{array}{l}\text { Tour guided by } \\
\text { library personnel }\end{array}$ & 150 & 38.7 \\
$\begin{array}{l}\text { Presentation by } \\
\text { library personnel }\end{array}$ & 76 & 19.6 \\
$\begin{array}{l}\text { Research skills } \\
\text { instruction in } \\
\text { library }\end{array}$ & 34 & 8.8 \\
$\begin{array}{l}\text { Research methods } \\
\text { course }\end{array}$ & 50 & 12.9 \\
$\begin{array}{l}\text { Term paper research } \\
\text { counseling }\end{array}$ & 35 & 9.0 \\
$\begin{array}{l}\text { None of the above } \\
\text { Other }\end{array}$ & 173 & 44.6 \\
\hline
\end{tabular}

have used, they were given a list of services and asked, "Which of the following have you had since you came to this university?" Their responses are summarized in table 5. As in the previous case, the students could choose as many as applied, so the percentages represent the total percentage who responded affirmatively. The category receiving the highest frequency was "none of the above," perhaps an indication that the students were not aware of the services, especially those which are part of the course-integrated instruction program targeted primarily at undergraduates. Some $38.7 \%$ of those surveyed had taken advantage of a tour of the library guided by library personnel; this service is typically offered at the beginning of the fall semester, before the first day of classes. It is an hour-long tour of the physical facilities and provides more information than instruction. Nineteen point six percent responded that they had attended a presentation on the library conducted by library personnel, and $12.9 \%$ had taken a course in research methods that included instruction in using library resources (but not necessarily conducted by library personnel). Fewer than $10 \%$ of the survey population had taken advan- tage of services such as term paper research counseling/consultation, research skills instruction sessions in the library, and an audiocassette self-guided tour of the library. These findings indicate that a large proportion of the international student population does not participate in instructional activities commonly offered in academic libraries, yet a sizable number does attend orientation activities offered at the beginning of the term.

\section{One of the major purposes of the} survey was to identify what aspects of library use were new to international students, or what features were different from libraries in their home countries.

To focus on the students' perception of the online catalog, they were asked, "Is the online catalog difficult for you to use?" To summarize the frequency distribution of their responses, $12.9 \%$ said "yes," $54.4 \%$ said "no," $28.8 \%$ said "sometimes," and $4.0 \%$ answered by writing their own response. The data indicate that most of the sample population say they did not have difficulty using the online catalog.

Additional frequency counts indicate that a large majority of the respondents had used computers before, but not for bibliographic access in libraries. Table 6 shows that when asked if they had used computers in a library before coming to the University of Illinois, $69.6 \%$ had not and $30.4 \%$ had. When asked if they had used computers for other purposes, such

TABLE 6

PREVIOUS USE OF COMPUTERS

\begin{tabular}{lcc}
\hline Purpose & Frequency & Valid \% \\
\hline In a library & & \\
Yes & 119 & 30.4 \\
No & 273 & 69.6 \\
For other purposes & & \\
Yes & 333 & 84.9 \\
No & 59 & 15.1 \\
\hline
\end{tabular}


TABLE 7

PREVIOUS USE OF LIBRARY COMPUTERS, BY DIFFICULTY USING ONLINE CATALOG

\begin{tabular}{lrrrrrr}
\hline & \multicolumn{6}{c}{ Difficulty Using Online Catalog } \\
\cline { 2 - 7 } Previous Use of Library Computers & \multicolumn{2}{c}{ Yes } & \multicolumn{3}{c}{ No } & \multicolumn{3}{c}{ Sometimes } \\
\cline { 2 - 7 } & No. & $\%$ & No. & $\%$ & No. & $\%$ \\
\hline Yes & 20 & 17.7 & 51 & 45.1 & 42 & 37.2 \\
No & 29 & 11.6 & 154 & 61.6 & 67 & 26.8 \\
\hline
\end{tabular}

Chi - square $=8.6 ; d f=2 ; p<.05 ;$ Cramer's $V=.154$.

TABLE 8

PREVIOUS USE OF OTHER COMPUTERS, BY DIFFICULTY USING ONLINE CATALOG

\begin{tabular}{|c|c|c|c|c|c|c|}
\hline \multirow[b]{3}{*}{ Previous Use of Other Computers } & \multicolumn{6}{|c|}{ Difficulty Using Online Catalog } \\
\hline & \multicolumn{2}{|c|}{ Yes } & \multicolumn{2}{|c|}{ No } & \multicolumn{2}{|c|}{ Sometimes } \\
\hline & No. & $\%$ & No. & $\%$ & No. & $\%$ \\
\hline Yes & 34 & 11.0 & 183 & 59.4 & 91 & 29.5 \\
\hline No & 15 & 27.3 & 22 & 40.0 & 18 & 32.7 \\
\hline
\end{tabular}

Chi - square $=12.4 ; d f=2 ; p<.01 ;$ Cramer's $V=.184$.

as word processing, database management, programming, etc., $84.9 \%$ had done so and only $15.1 \%$ had not.

The hypothesis of interest is that international students with prior experience using computers in libraries might not have experienced difficulty using the online catalog at the University of Illinois. The null hypothesis being tested is that prior experience using computers makes little difference with regard to difficulty the students experience using the online catalog. For the procedure of hypothesis testing, the null hypothesis can be rejected if the observed significance level (probability) is less than 0.05 . A crosstabulation was performed to determine the relationship between the respondents' difficulty using the online catalog and their prior use of computers in libraries. Based on the frequency distributions, it was expected that students who had prior experience using any kind of computers in libraries would find the online catalog less difficult to use, perhaps because of familiarity with the concept of bibliographic access or with typical searching patterns. Table 7 shows that this was primarily the case. Of those students who had previously used computers in libraries, only $17.7 \%$ said the online catalog was difficult, while $45.1 \%$ said it was not difficult to use. Some $37.2 \%$ reported that it was sometimes difficult to use. Because the probability is small $(0.013)$, the null hypothesis can be rejected; the low probability indicates that it is quite unlikely that the two variables are independent in the population. To test the strength of the association, a Cramer's $V$ was conducted; in this statistical test, a value of zero corresponds to no association and a value of one to perfect association. For table 7, the value of Cramer's $V$ is 0.154 , indicating a fairly low measure of association. In the analysis represented by table 7 , and in all further tables that represent cross-tabulations of the "difficulty using the online catalog" variable, the "other" response was recorded as missing because it was chosen by less than $5 \%$ of the respondents (fewer than 19 people). Next, a cross-tabulation was performed to determine the relationship between the respondents' difficulty using the online catalog and their prior use of computers for other purposes. Table 8 summarizes this relationship. Of the students who had previously used computers for purposes other than library information retrieval, only $11.0 \%$ said the online catalog was difficult, while $59.4 \%$ said it was not difficult to use. Conversely, of 
TABLE 9

PRIOR USE OF LIBRARY COMPUTERS, BY PREPAREDNESS TO USE UNITED STATES LIBRARIES

\begin{tabular}{lccccccc}
\hline & \multicolumn{3}{c}{ Preparedness to Use United States Libraries } \\
\cline { 2 - 7 } Prior Use of Library Computers & \multicolumn{2}{c}{ Very Prepared } & \multicolumn{2}{c}{ Somewhat } & \multicolumn{2}{c}{ Not at All } \\
\cline { 2 - 7 } & No. & $\%$ & No. & $\%$ & No. & $\%$ \\
\hline Yes & 46 & 41.8 & 49 & 25.3 & 22 & 25.6 \\
No & 64 & 58.2 & 145 & 74.7 & 64 & 74.4 \\
\hline
\end{tabular}

Chi - square $=10.2 ; d f=2 ; p<.01 ;$ Cramer's $V=.161$.

TABLE 10

PRIOR USE OF OTHER COMPUTERS, BY PREPAREDNESS TO USE UNITED STATES LIBRARIES

\begin{tabular}{lrrrrrr}
\hline & \multicolumn{3}{c}{ Preparedness to Use United States Libraries } \\
\cline { 2 - 7 } Prior Use of Other Computers & \multicolumn{2}{c}{ Very Prepared } & \multicolumn{2}{c}{ Somewhat } & \multicolumn{2}{c}{ Not at All } \\
\cline { 2 - 7 } & No. & \multicolumn{1}{c}{$\%$} & No. & $\%$ & No. & $\%$ \\
\hline Yes & 103 & 93.6 & 158 & 81.4 & 70 & 81.4 \\
No & 7 & 6.4 & 36 & 18.6 & 16 & 18.6 \\
\hline
\end{tabular}

Chi - square $=9.16 ; d f=2 ; p=.01 ;$ Cramer's $V=.153$.

those students who did not have previous experience with computers for other purposes, a larger percentage $(27.3 \%$ ) had difficulty with the online catalog, but a smaller percentage $(40.0 \%)$ did not have difficulty. Based on a chi-square analysis, a statistically significant relationship $(p=0.002)$ between reported difficulty using the online catalog and previous experience with computers for other purposes exists, but the value of Cramer's $V$ is 0.185 , indicating that the strength of association is fairly low.

An analysis of the relationship between prior use of computers in libraries and the degree to which students are prepared to use American libraries is reported in table 9. Of students who felt very prepared to use American college and university libraries, $41.8 \%$ had used computers in libraries previously but $58.2 \%$ had not. Of students who felt somewhat prepared, only $25.3 \%$ had used computers in libraries, while $74.7 \%$ of this group had not used computers in the library setting. And of those not at all prepared, again, $25.6 \%$ had used computers in libraries previously, while $74.4 \%$ had not. The chi-square computa- tion for this relationship is statistically significant, with $p=0.006$, so it can be said that having used computers in libraries before and feeling prepared to use American libraries are not independent. However, the Cramer's $V$ value is 0.162 , indicating that the strength of association is low. Table 10 summarizes the similar, yet much more pronounced, relationship between prior use of computers for other purposes and students preparation to use American libraries. Of those students who were very prepared, $93.6 \%$ had used computers before for other purposes. Of those who were somewhat prepared, $81.4 \%$ had used computers for other purposes, but of those not at all prepared, $81.4 \%$ had also used computers before for other purposes. There does appear to be a statistically significant (with $p=0.010$ ) association between international students' prior use of computers for other purposes and their feeling prepared to use American libraries. However, the strength of association is low, at 0.153 , and because $85.9 \%$ of those surveyed had used computers for other purposes, the results may be misleading. 
TABLE 11

NEWNESS OF ONLINE CATALOG, BY PREPAREDNESS TO USE UNITED STATES LIBRARIES

\begin{tabular}{lrrrrrrr}
\hline & \multicolumn{3}{c}{ Preparedness to Use United States Libraries } \\
\cline { 2 - 7 } Newness of Online Catalog & \multicolumn{2}{c}{ Very Prepared } & \multicolumn{2}{c}{ Somewhat } & \multicolumn{2}{c}{ Not at all } \\
\cline { 2 - 7 } & No. & $\%$ & No. & $\%$ & No. & $\%$ \\
\hline Yes & 66 & 34.6 & 81 & 42.4 & 44 & 23.0 \\
No & 42 & 21.6 & 111 & 57.2 & 41 & 21.1 \\
\hline
\end{tabular}

Chi - square $=10.1 ; d f=2 ; p<.01 ;$ Cramer's $V=.162$

TABLE 12

NEWNESS OF ONLINE CATALOG, BY DIFFICULTY USING ONLINE CATALOG

\begin{tabular}{lccccccc}
\hline & \multicolumn{4}{c}{ Difficulty Using Online Catalog } \\
\cline { 2 - 7 } Newness of Online Catalog & \multicolumn{3}{c}{ Yes } & \multicolumn{3}{c}{ No } & \multicolumn{2}{c}{ Sometimes } \\
\cline { 2 - 7 } & No. & $\%$ & No. & $\%$ & No. & $\%$ \\
\hline Yes & 23 & 12.7 & 96 & 53.0 & 62 & 34.3 \\
No & 26 & 14.2 & 110 & 60.1 & 47 & 25.7 \\
\hline
\end{tabular}

Chi - square $=3.18 ; d f=2 ; p>.05 ;$ Cramer's $V=.093$

In analyzing the relationship between the newness of the online catalog to users and their preparation for American libraries, table 11 shows that of those who reported that the online catalog was new to them, $57.2 \%$ felt only somewhat prepared to use American libraries, while $21.6 \%$ felt very prepared and $21.1 \%$ felt not at all prepared. The chisquare test revealed this association to be statistically significant, with a probability of 0.006 . Using the Cramer's $V$ test, the strength of association is low at 0.162 . Table 12 summarizes the cross-tabulation of responses to the questions dealing with newness of the online catalog to users and their difficulty with it. As stated earlier, because of small cell size, it was necessary to record the "other" response to the "difficulty" variable as missing for this analysis. Based on a chisquare analysis, the relationship represented in table 12 is not statistically significant since the probability is 0.203 (testing at 0.05). The strength of association is very low, with the Cramer's $V$ test yielding a value of 0.093 . The results indicate that of persons who said the online catalog was not new to them, only $12.7 \%$ had difficulty using it, $34.3 \%$ sometimes had difficulty, and $53.0 \%$ did not have difficulty. Likewise, for those who said the online catalog was new, the percentages for difficulty of use were similar; the figures show that nearly the same number of persons reported yes as reported no to the newness question.

Table 13 summarizes the relationship between international students' preparation for American libraries and their difficulty using the online catalog. Based on chi-square analysis, the observed significance level of 0.007 indicates that there is a statistically significant association between the students' preparation for American college and university libraries and the difficulty they experience using the online catalog. The Cramer's $V$ test yielded a value of 0.139 , which represents a low strength of association. Of those who said they did have difficulty using the catalog, only $18.4 \%$ felt very prepared to use United States academic libraries, while $51.0 \%$ were only somewhat prepared and $30.6 \%$ were not at all prepared. Of those who said they did not have difficulty with the online catalog, $34.8 \%$ felt very prepared, $49.5 \%$ felt somewhat prepared, but only $15.7 \%$ were not at all prepared. The rela- 
TABLE 13

PREPAREDNESS TO USE UNITED STATES LIBRARIES, BY DIFFICULTY USING ONLINE CATALOG

\begin{tabular}{lrrrrrr}
\hline & \multicolumn{6}{c}{ Difficulty Using Online Catalog } \\
\cline { 2 - 7 } Preparedness to Use & \multicolumn{2}{c}{ Yes } & \multicolumn{1}{c}{ No } & \multicolumn{2}{c}{ Sometimes } \\
\cline { 2 - 7 } Online Catalog & No. & $\%$ & No. & $\%$ & No. & $\%$ \\
\hline Very prepared & 9 & 18.4 & 71 & 34.8 & 22 & 20.2 \\
Somewhat prepared & 25 & 51.0 & 101 & 49.5 & 58 & 53.2 \\
Not at all prepared & 15 & 30.6 & 32 & 15.7 & 29 & 26.6 \\
\hline
\end{tabular}

Chi - square $=14.04 ; d f=4 ; p<.01 ;$ Cramer's $V=.139$

TABLE 14

NUMBER OF YEARS IN UNITED STATES BY DIFFICULTY USING ONLINE CATALOG

\begin{tabular}{lrrrrrr}
\hline & \multicolumn{4}{c}{ Difficulty Using Online Catalog } \\
\cline { 2 - 7 } Number of Years in United States & \multicolumn{2}{c}{ Yes } & \multicolumn{1}{c}{ No } & \multicolumn{2}{c}{ Sometimes } \\
\cline { 2 - 7 } & \multicolumn{1}{c}{ No. } & $\%$ & No. & $\%$ & No. & $\%$ \\
\hline Less than 1 year & 19 & 22.1 & 33 & 38.4 & 34 & 39.5 \\
1-3 years & 23 & 13.1 & 106 & 60.6 & 46 & 26.3 \\
4-6 years & 6 & 7.5 & 53 & 66.3 & 21 & 26.3 \\
6 years or more & 0 & 0 & 13 & 65.0 & 7 & 35.0 \\
\hline
\end{tabular}

Chi - square $=20.72 ; d f=6 ; p<.01 ;$ Cramer's $V=.169$

tionship between the number of years the international students had been in the United States and their difficulty using the online catalog is represented in table 14 . Here, the hypothesis of interest is that international students who have been in the United States longer might not experience difficulty using the online catalog. The cross-tabulation shows that $38.4 \%$ of respondents who had spent less than one year in the United States did not have difficulty with the online catalog, while $22.1 \%$ did. However, of those who had spent one to three years in the United States, $60.6 \%$ did not experience difficulty and only $13.1 \%$ did. Further, of those who had already spent four to six years in the United States, $66.3 \%$ did not have difficulty and a very small percentage $(7.5 \%)$ did. The null hypothesis can safely be rejected since the observed significance level is 0.002 ; yet the strength of the association is fairly low, with a Cramer's $V$ value of 0.169 .

\section{IMPLICATIONS}

It is important for any library to examine the characteristics of its user population and to develop and implement services appropriate to the users' needs. The analysis presented here describes certain characteristics of the international student population at a large university and illustrates a number of the group's use patterns within the context of a large, highly automated library system. The results of the study demonstrate that a basic, but crucial factor to be considered when planning for bibliographic instruction activities, is the status of international students. It is only natural to aim course-integrated library instruction programs at undergraduates; but libraries must be aware that there are other new students with special needs who may not be taking advantage of the most commonly offered services and instruction activities. If most of the international student population are graduate students, 
with advanced knowledge of the literature in their fields, (yet perhaps unfamiliar with technological advances in bibliographic access and the services offered by large United States academic libraries), then a distinct avenue must be created to reach them. This must be distinct from the process aimed at undergraduates. At Illinois the Office of International Student Affairs is more than happy to include the library on its agenda as a major component of the orientation for new international students on campus. A special opportunity such as this is an excellent way for librarians to present the library and themselves in a positive light, to provide an introduction to bibliographic access systems and basic services, and to extend an invitation for further instruction. ${ }^{12}$

\section{REFERENCES AND NOTES}

1. Robin Wilson, "Foreign Students in U.S. Reach a Record 386,000," Chronicle of Higher Education 37 (November 28, 1990): 1, 13.

2. Joan Ormondroyd, "The International Student and Course-Integrated Instruction: The Librarian's Perspective," Research Strategies 7 (Fall 1989): 148-58.

3. Frances F. Jacobson, "Bibliographic Instruction and International Students," Illinois Libraries 70 (Dec. 1988): 628-33.

4. Roberto G. Trujillo and David C. Weber, "Academic Library Responses to Cultural Diversity: A Position Paper for the 1990s," Journal of Academic Librarianship 17 (July 1991):3, 157-61.

5. Janet E. Welch and Errol Lam, "The Library and the Pluralistic Campus in the Year 2000: Implications for Administrators," Library Administration and Management 5 (Fall 1991): 4, 212-16.

6. Dania M. Bilal, "Problems of Foreign Students in Using U.S. Libraries and the Difficulties of Translating an International Education to Lebanon," in Tallman and Ojiambo, Translating an International Education to a National Environment (Metuchen, N.J.: Scarecrow, 1990), 23.

7. Dania M. Bilal, Library Knowledge of International Students from Developing Countries: A Comparison of Their Perceptions with Those of Reference Librarians (Ann Arbor, Mich.: University Microfilms International,1988); Kwasi Sarkodie-Mensah, Foreign Students and U.S. Academic Libraries (Ann Arbor, Mich.: University Microfilms International, 1989); Ting Ming Lai, A Comparative Study of the Use of Academic Libraries by Undergraduates in the United States and Taiwan (Ann Arbor, Mich.: University Microfilms International, 1990).

8. Oliveira, Silas Marques de, "The Compatibility between American Library and Information Science Programs and Foreign Countries' Needs: An Exploratory Study," in Tallman and Ojiambo, Translating an International Education to a National Environment (Metuchen, N.J.: Scarecrow, 1990), 98.

9. Ibid., 99.

10. Sarkodie-Mensah, Foreign Students and U. S. Academic Libraries.

11. The author worked closely with the Graduate School of Library and Information Science's Library Research Center to design questions of consistent format for ease of completion by the survey participants and to ensure accurate coding of the data.

12. General library orientation for international students was first organized through the Undergraduate Library at UIUC in 1988 . The service successfully continues in cooperation with the C. Walter \& Gerda B. Mortenson Center for International Library Programs. 


\section{New from ALA Books}

\section{Meeting the information demands of today's library and beyond.}

\section{FISCAL Directory of Fee-Based Research and Information Services Steve Coffman, compiler}

Approximately 550 listings of fee-based information services providers, including libraries and commercial sources, detail products, services, prices, subject strengths and resources available. Copublished by the Los Angeles Public Library.

$\$ 65.00$ pbk. $\quad 650$ p. $\quad 1992$

ALA Order Code 2161-2-0011

\section{Major U.S. Statistical Series:}

Definitions, Publications, Limitations

Jean Slemmons Stratford

and Juri Stratford

A specialized reference work compiled to provide the reader an understanding of a wide variety of federal statistical data and guidance in locating the published series which report them on a regular basis.

$\$ 27.50$ pbk. 150p. 1992

ALA Order Code 0600-1-0011

\section{The United States in the Global}

\section{Economy: Challenges and Policy}

\section{Choices}

The Last Quarter Century: A Guide to the Issues and the Literature, \#2

John J. Accordino

Accordino explores how the emerging global economy affects domestic economic health, presents policy alternatives and provides readers the means to evaluate the various approaches. Economic, industrial and trade policies are covered from conservative, liberal, and radical positions.
$\$ 38.00$ pbk. $\quad 450$ p. 1992 ALA Order Code 0591-9-0011

\section{Available from the Association of College and Research Libraries}

\section{New!}

\section{Women's Studies Collection}

\section{Development Policies}

Collection Development and Bibliography

Committee, Women's Studies Section, ACRL

Complete policy statements from 16 university libraries illustrate the range of issues unique to women's studies and provide models of existing policies. The RLG Conspectus: Women's Studies supplemental guideline is included as an appendix.

$\$ 35.95$ pbk. $\quad 122$ p. $\quad 1992$

ALA Order Code 7596-8-0011

\section{The Evolving Educational Mission of the Library \\ Betsy Baker and Mary Ellen Litzinger}

Strategic issues on instructional programs, librarians' roles on campus, information literacy, the information explosion, new educational constituencies, and the resultant need for changes in the information science curricula are presented.

\section{$\$ 29.95$ pbk. 202p. 1992}

ALA Order Code 7584-4-0011

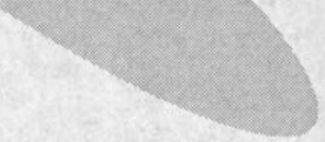

50 East Huron Street

Chicago, IL 60611

To order call 1-800-545-2433 and press 7 . 